\title{
MANAJEMEN PELAYANAN KANTOR KEMENTERIAN AGAMA KABUPATEN LAMONGAN DI ERA INDUSTRIALISASI 4.0
}

\author{
Hidayatul Fitria, Irma Erviyana Ningrum, Nur Hidayati Roihannah \\ UIN Sunan Ampel, Surabaya - Indonesia | hidayatulfitria22@gmail.com
}

\begin{abstract}
Abstrak: Penelitian ini mengkaji tentang pelayanan manajemen kantor di Kantor Kementerian Agama Kabupaten Lamongan. Fokus dalam penelitian ini adalah gambaran layanan manajemen kantor di Era Industrialisasi 4.0 di Kantor Kementerian Agama Kabupaten Lamongan. Berdasarkan fokus penelitian tersebut, selanjutnya penelitian ini bertujuan untuk mengetahui gambaran pelayanan manajemen kantor pada Kantor Kementerian Agama Kabupaten Lamongan. Pendekatan yang digunakan dalam penelitian ini adalah pendekatan deskriptif kualitatif, sedangkan yang menjadi unit analisis dalam penelitian ini adalah Kepala Sub Bagian TU, Kepala Seksi masing-masing bidang dan Tamu Kantor Kementerian Agama Kabupaten Lamongan. Teknik pengumpulan data yang digunakan adalah observasi, wawancara dan dokumentasi. Berdasarkan hasil reduksi data maka hasil penelitian ini menunjukkan bahwa, layanan manajemen kantor yang berkualitas di Kantor Kementerian Agama Kabupaten Lamongan masih belum terlaksana secara efektif dan efesien.
\end{abstract}

Keywords: Pelayanan, Manajemen, Industrialisasi

\section{Pemdahuluan}

Perkembangan ilmu pengetahuan dan teknologi kini berjalan dengan sangat pesat. Riset dalam berbagai bidang digalakkan di seluruh penjuru dunia demi terciptanya manfaat berkelanjutan bagi kehidupan makhluk hidup. Sebagai konsekuensi, berbagai industri harus bersiap diri dan beradaptasi dengan perkembangan teknologi, apabila tidak mau tertinggal dan merugi. Dalam industri 4.0 yang terjadi adalah adanya otomasi dan digitalisasi segala aspek industri dalam rangka menghasilkan produk yang memuaskan kebutuhan konsumen. Campur tangan manusia atau kegiatan 
manual akan berkurang dengan adanya teknologi maju yang menggantikannya.

Pemerintah Indonesia melalui Kementerian Agama telah menyiapkan langkah strategis untuk menghadapi revolusi industri 4.0 (https://kemenag.go.id/). Pertama yaitu mendorong agar angkatan kerja di Indonesia terus belajar dan meningkatkan ketrampilannya untuk memahami penggunaan teknologi internet of things atau mengintegrasikan kemampuan internet dengan lini produksi di industri. Langkah kedua yaitu industri nasional harus dapat menggunakan teknologi digital seperti big data, cyber security, cloud dan augmented reality. Dari langkah strategis tersebut ditujukan untuk meningkatkan daya saing industri nasional baik di regional maupun internasional. Seiring dengan hal tersebut, diperlukan langkah-langkah inovatif dan adaptif yang harus dilakukan oleh pelaku industri untuk dapat bertahan di era revolusi industri 4.0. Teknologi digital dan internet tidak dapat luput dari perhatian manajemen industri. Seluruh kegiatan harus dipersiapkan pada kegiatan berbasis teknologi digital.1

Kantor Wilayah Kementerian Agama Kabupaten Lamongan sebuah instansi yang besar dan memiliki cabang yang ada dibawahnya seperti Kantor Urusan Agama yang memiliki khalayak yang luas dan tersebar diberbagai daerah sekitar Lamongan. Untuk itu penggunaan website sebagai media penunjang transparansi informasi sangat penting sekali, karena dengan menggunakan media online kegiatan komunikasi akan lebih efektif dan mudah dilakukan walaupun perbedaan lokasi sangat jauh dan lebih efisien dalam hal biaya dan waktu.

Pelayanan publik yang menjadi fokus pemerintahan dalam upaya mempercepat akselerasi pembangunan di daerah dalam mencapai tingkat kesejahteraan masyarakat. Maka pelayanan public masalah yang sangat krusial, dimana upaya pemerintah untuk memenuhi kebutuhan substansial yakni kebutuhan akan agama. Maka pelayanan keagamaan masyarakat perlu ditingkatkan

1 Dian Amintapratiwi Purwandini, Irwansyah, "KOMUNIKASI KORPORASI PADA ERA INDUSTRI 4.0”, Jurnal Ilmu Sosial Vol. 17 |No. 1 |Edisi Januari - Juni 2018 |Hal.53-63 
kualitasnya, baik melalui debirokratisasi maupun deregulasi pelayanan keagamaan dalam bentuk kebijakan yang akan bermuara pada terciptanya pelayanan prima.

Untuk mendukung kinerja pelayanan dalam kantor, maka unit pengelola informasi public harus didukung oleh sumber daya manusia berkualitas yang didukung oleh tersedianya fasilitas teknologi komunikasi-informasi yang memadai. Faktor lain yang harus menjadi perhatian adalah merubah karakter yang mematutmatut sebagai kelas dominan menjadi pelayan publik di bidang pemenuhan informasi kepada media massa maupun masyarakat pada umumnya sebagai pengguna informasi.

Internet menjadi media yang sangat vital untuk mendukung kemajuan/perkembangan dan menjadi media untuk menyampaikan informasi kepada masyarakat luas serta menjadi alat komunikasi yang paling cepat, tepat, efektif dan efisien. Searah dengan kondisi tersebut, pada saat ini pemerintah telah menggalakkan pemanfaatan teknologi informasi (internet) dalam menunjang aktifitas kegiatan pemerintahannya. Bagi pemerintah, internet digunakan melalui website pemerintah. Karena website memberikan banyak manfaat diantaranya dapat meningkatkan personal brand (nama baik) bagi pemilik website. Website merupakan sebuah halaman di internet yang memuat informasi teks, gambar, animasi, suara, video dan atau gabungan dari semuanya.

Dengan memanfaatkan perkembangan teknologi melalui website, adalah salah satu sarana yang harus dimanfaatkan oleh badan pemberi informasi, karena melalui website, pemerintah dengan gampang menyebarkan segala informasi yang dibutuhkan oleh masyarakat. Tersedianya unit pengelola informasi dan sumber daya manusia, serta fasilitas yang memadai dan efisien dengan kecepatan yang maksimals, maka badan pengelola diharapkan dapat menyediakan informasi yang akurat untuk kepentingan media massa. Kemajuan teknologi informasi dan komunikasi dalam bidang pemerintahan diwujudkan dengan sebuah sistem yang disebut dengan e-government atau electronic government. Egovernment merupakan wujud keinginan pemerintah dalam upaya 
mendorong bangsa Indonesia menuju masyarakat informasi. Kebutuhan akan tersedianya informasi setidaknya memiliki sifatsifat informasi yang cakupannya luas, mudah digunakan, terkini, aman, serta murah. 2

Sistem pelayanan yang berlaku dan sering di praktikkan pada saat ini, pada kenyataannya dirasakan masyarakat masih ada hambatan birokratis. Terkesan dalam kebijakannya pemerintah sangat dilematis. Di satu sisi masyarakat menaruh harapan besar akan pelayanan yang berkualitas, di sisi lain sering masyarakat keberatan jika terlalu banyak jenis pungutan, baik yang resmi maupun yang tidak resmi. Sistem yang demikian tentunya harus segera dilakukan penyempurnaan. Ditandai dengan: (1) prosedur pengurusan administrasi yang berbelit-belit dan terlalu banyak persyaratan yang harus dipenuhi, (2) biaya yang terlalu tinggi (3) waktu penyelesaian Administrasi terlalu lama, (4) persyaratan tidak relevan, dan (5) kinerja pelayanan yang sangat rendah.

Pada sisi lain pelayanan yang dilakukan oleh pengelola birokratis belum optimal dan system pelayanan yang sedang dijalankan masih memprihatinkan. Efisiensi dan efektifitas dari waktu dan biaya masih rendah, perbedaan antara waktu penyelesaian dan biaya dari yang diperlukan dan yang diinginkan masyarakat masih sangat jauh. Ketidakpastian pelayanan dengan mudah ditemukan hampir setiap jenis pelayanan publik. Sebagaimana kita ketahui bahwa ada tiga fungsi reformasi secara fundamental yaitu: 1) Revitalisasi, 2) Restrukturisasi, 3) Refungsionalisasi. Dalam kajian penelitian ini maka Refungsinalisasi birokrasi dibagi dalam tiga dimensi yaitu: 1) Fungsi pelayan public, 2) Fungsi pengaturan, dan 3) Fungsi

${ }^{2}$ Zulfahmi, Muhammad Badri, Listiawati Susanti, Efektivitas media EGovernment dalam mendukung Transparansi Informasi di Kantor Kementerian Agama provinsi Riau, Jurnal Riset Mahasiswa Dakwah dan Komunikasi, Vol. 1 No. 1, Maret 2019 Hal 03 
pengawasan.3 Pada praktik di lapangan proses pelayanan keagamaan pada Kementerian Agama Kabupaten Lamongan antara lain: Fungsi pelayanan yaitu tugas pokok dan fungsi belum berjalan maksimal. Fungsi pengaturan yaitu teknis administrasi pelayanan, biaya administrasi, waktu pelaksanaan, daftar petugas jaga dan kejelasan aturan belum sesuai dengan standar operasional prosedur. Fungsi pengawasan yaitu : manajemen pengawasan belum berjalan secara maksimal.

Gambaran awal terhadap pada pelayanan keagamaan di Kantor Kementerian Agama Kabupaten Lamongan sebagai bentuk sikap dan prilaku yang harus diemban dalam melaksanakan tugas dan fungsinya sesuai dengan aturan yang telah ditetapkan sebelumnya.

Dengan latar belakang peneleitian yang fokus pada manajemen pelayanan kantor di Era Industrialisasi 4.0. Maka, penelitian yang akan dilakukan berjudul Manajemen Pelayanan Kantor Kementerian Agama Kabupaten Lamongan Di Era Industrialisasi 4.0.

Berdasarkan latar belakang, maka rumusan masalah umumnya "Bagaimanakah manajemen pelayanan Kantor Kemeterian Agama Kabupaten Lamongan?". Sedangkan rumusan masalah khususnya: (a) Bagaimanakah manajemen pelayanan Kantor di Era Industrialisasi 4.0?; (b) Bagaimanakah Standart Operasional Prosedur pelayanan Kantor Kementerian Agama Kabupaten Lamongan?; (c) Bagaimanakah pelaksanaan Standart Operasional Prosedur pelayanan di setiap bidang Kantor Kementerian Agama Kabupaten Lamongan?.

Tujuan dari penelitian ini untuk mengetahui manajemen pelayanan Kantor Kementerian Agama Kabupaten Lamongan. Sedangkan manfaat dari penelitian ini guna mahasiswa dapat memperoleh informasi mengenai pelaksanaan manajemen pelayanan Kantor Kementerian Agama Kabupaten Lamongan.

${ }^{3}$ Arifuddin Siraj, Refungsionalisasi Aparat Pelayanan Keagamaan di Kantor Kementerian Agama Kota Makassar, Jurnal Ilmiah Ilmu Administrasi Publik: Jurnal Pemikiran dan Penelitian Administrasi Publik, Volume 8 Nomor 1 Januari - Juni 2018. Hal 47 


\section{Metodologi}

Penelitian ini adalah penelitian deskriptif kualitatif. Dalam pelaksanaanya subjek yang diamati adalah Kepala Sub Bagian TU, Kepala Seksi masing-masing bidang dan Tamu Kantor Kementerian Agama Kabupaten Lamongan. Waktu 24 Agustus- 14 Oktober 2020. Lokasi penelitian ini berada di Kantor Kementerian Agama Kabupaten Lamongan. Teknik pengumpulan data penelitian kali ini menggunakan teknik wawancara, observasi dan studi dokumentasi.

Analisis data yang terkumpul berkaitan dengan penelitian tentang manajemen pelayanan yang ada di Kementerian Agama Kabupaten Lamongan, yang meliputi pelayanan di setiap seksi yang ada di Kantor Kementerian Agama Kabupaten Lamongan. Penelitian ini adalah penelitian jenis deskriptif kualitatif. Teknik analisis dalam penelitian ini adalah pengumpulan data, reduksi data, penyajian data, dan kesimpulan. Prosedur analisis data itu meliputi tahapan:

\section{Pengumpulan data (data collection)}

Data-data yang diperoleh dari Kantor Kemterian Agama Kabupaten Lamongan berasal dari narasumber dengan tidak ada penambahan dari peneliti. Pencatatan dilakukan berdasarkan hasil wawancara. Dibuat dengan bentuk catatan kecil. Catatan tersebut kemudian didiskripsikan menjadi sebuah narasi deskriptif dan jurnal reflektif atas fenomena yang terjadi dilapangan.

\section{Reduksi Data (Reduction)}

Reduksi data merupakan proses pemilihan, pemusatan perhatian, pada penyederhanaan, pengabsrakkan dan transformasi data kasar yang muncul dari catatan lapangan. Reduksi data merupakan wujud analisis yang menajamkan, mengklafikasikan, mengarahkan, membuang data yang tidak berkaitan dengan aktivitas manajemen pelayanan di Era Industrialisasi 4.0 yang ada di Kementerian Agama Kabupaten Lamongan. Selanjutnya dibuat ringkasan, pengkodean, penelusuran tema-tema, membuat catatan kecil yang dirasakan penting pada kejadian. Pencatatanan yang dilakukan hanya yang berkaitan dengan manajemen pelayanan perihal prosuder pelayanan di setiap seksi. 


\section{Penyajian Data (display)}

Langkah sesudah mereduksi data adalah penyajian data. Teknik penyajian data dalam kualitatif adalah berupa uraian, bagan, hubungan antar katagori, dan sejenisnya. Pada tahap ini disajikan data hasil temuan dilapangan dalam bentuk teks naratif, yaitu uraian verbal tentang pelaksanaan pelayanan yang ada di Kantor Kementerian Agama Kabupaten Lamongan di Era Industrialisasi 4.0.

\section{Penarikan Kesimpulan dan Verifikasi}

Dalam analisis data kualitatif menyimpulkan dan kesimpulan verifikasi. Dengan demikian kesimpulan dalam penelitian kualitatif mungkin dapat menjawab rumusan masalah yang dirumuskan pada awal penelitian. Namun juga terdapat kemungkinan tidak. Dalam penarikan kesimpulan penelitian dapat dilihat proses pelayanan pegawai kepada tamu, baik itu internal maupun eksternal lingkungan kantor.

\section{Hasil dan Pembahasan}

Hasil penelitian menunjukkan bahwa Manajemen Pelayanan Kantor di Era Industralisasi 4.0 pada Program tergolong cukup efektif yang ditinjau dari indikator:

\section{Manajemen Pelayanan Kantor Era Industralisasi 4.0}

Manajemen pelayanan adalah seperangkat kemampuan organisasi khusus untuk memberikan hasil kepada pelanggan dalam bentuk layanan. "Kemampuan Khusus Organisasi" ini meliputi proses, kegiatan, fungsi dan peran yang menggunakan penyedia layanan dalam memberikan layanan kepada pelanggan mereka, serta kemampuan untuk membangun struktur organisasi yang cocok, mengelola pengetahuan dan memahami bagaimana memfasilitasi hasil yang menciptakan nilai. Manajemen Pelayanan Kantor pada dasarnya ditujukan untuk mewujudkan pelayanan yang prima, yaitu pelayanan yang memenuhi standar yang sudah ditetapkan. Guna mewujudkan pelayanan prima, maka manajemen harus mewujudkan 3 kepuasan, yaitu kepuasan pelanggan (masyarakat), kepuasan organisasi dan kepuasan pegawai. 
Dalam manajemen pelayanan kantor harus memenuhi prisipprinsip manajemen pelayanan, diantaranya:

\section{Perencanaan (Planning)}

Perencanaan adalah suatu kegiatan yang didahului dengan membuat rencana untuk mencapai tujuan yang telah ditetapkan sebelumnya. Hal ini sejalan dengan apa yang diterapkan Kementerian Agama Kabupaten Lamongan dalam melaksanakan pelayanan di setiap bidang. Dalam membuat suatu kegiatan, tentunya hal yang pertama dilakukan adalah menyusun rencana. Di Kantor Kementerian Agama Kabupaten Lamongan bahwa perencanaan yang dilakukan merupakan penentu serangkaian kegiatan dan penjadwalan yang akan dilaksanakan dalam melayani tamu kantor di Kabupaten Lamongan.

\section{Pengorganisasian (Organizing)}

Setelah penetapan rencana selanjutnya yang dilakukan oleh Kantor Kementerian Agama Kabupaten Lamongan adalah pengorganisasian. Pengorganisasian sangat penting dilakukan dengan tujuan memberikan pembagian tugas kerja yang menjadi tugas dan tanggung jawab masing-masing staf dalam setiap bidang.

Staf yang akan diberikan tugas sesuai dengan tanggung jawab masing-masing dibidangnya. Hal ini dimaksudkan agar masingmasing staf dapat dengan leluasa menyelesaikan tugas-tugas yang diberikan. Tahap selanjutnya adalah menjalin hubungan koordinasi antar staf agar terbentuk suasana kerja yang menyenangkan dan terjalin keterbukaan dalam menyelesaikan tugasnya.

\section{Pelaksanaan (Actuating)}

Setelah dilakukan perencanaan dan pengorganisasian maka tahap selanjutnya pelaksanaan pelayanan. Pelaksanaan pelayanan merupakan gerak aksi implementasi program yang telah direncanakan. Dalam hal ini yang dimaksud dengan pelaksanaan (Actuating) yaitu pelaksanaan dari pemberian pelayanan kepada para tamu kantor yang ada di Kantor Kementerian Agama Kabupaten Lamongan.

\section{Pengawasan (Controlling)}

Pengawasan merupakan salah satu fungsi manajemen yang dibutuhkan untuk menjamin agar semua keputusan rencana dan 
pelaksanaan kegiatan mencapai tujuan dengan hasil yang baik dan efisien. Proses pengawasan di Kantor Kementerian Agama Kabupaten Lamongan dilakukan oleh atasan kepada bawahan untuk menjamin bahwa kegiatan yang sudah direncanakan terlaksana dengan baik. Atasan atau Kepala Kantor Kementerian Agama Kabupaten Lamongan pada dasarnya dalam menjalankan pengawasan harus meliputi pemberian pelayanan yang harus dilakukan di setiap bidang atau seksi. Dengan adanya manajemen pelayanan yang baik dapat menkodinir pimpinan terkait hal lainnya untuk mampu mengambil ahli dalam melakukan pengawasan di Kantor Kementerian Agama Kabupaten Lamongan.

Revolusi Industri 4.0 merupakan perubahan dimana untuk memproduksi suatu barang, memanfaatkan mesin sebagai tenaga penggerak dan pemroses. Revolusi industri ini hadir untuk menjawab permasalahan efektifitas dan efisiensi dalam memproduksi suatu barang. Revolusi Industri 4.0 ini mengintregasikan antara teknologi cyber dan teknologi otomatisasi. Dampak era revolusi industri 4.0 adalah dalam penerapannya tidak lagi memberdayakan tenaga kerja manusia, sebab semuanya sudah menerapkan konsep otomatisasi. Dengan demikian tingkat efektifitas dan efisiensi waktu bisa meningkat. Dimana waktu merupakan hal vital dalam dunia industri. Disamping manfaat revolusi industri 4.0 terhadap bidang prindustrian, manfaat teknologi juga bisa dirasakan oleh semua orang. Saat ini akses informasi sangat mudah dan bisa dilakukan kapan dan di mana saja dengan adanya jaringan internet.

Setelah mereduksi data hasil wawancara terkait manajemen pelayanan Kantor Kementerian Agama Kabupaten Lamongan di era industrialisasi 4.0 masih kurang efektif dan efisien. Manajemen Pelayanan di Kantor Kementerian Agama Kabupaten Lamongan sudah baik, namun belum semaksimal mungkin dan masih banyak kekurangan-kekurangan yang dimiliki oleh pegawai dalam melaksanakan pelayanan kepada masyarakat. Pelayanan di Kantor Kementerian Agama Kabupaten Lamongan masih sebagian bersifat manual. Meskipun sudah memasuki era industrialisasi 4.0 seperti ini. Seharusnya di Era Industrialisasi 4.0 ini, segala aspek pelayanan 
baik itu dari Bidang Pendidikan Madrasah, Bidang Pendidikan Islam, Pendidikan Diniyah dan Pondok Pesantren, Bimbingan Masyarakat, Penyelenggaga Haji dan Umroh, Pelayanan Terpadu Satu Pintu, Tata Usaha dan Kepegawaian, Keuangan dan yang lainnya sudah menggunakan aplikasi dalam pelayanan. Agar masyarakat tidak lagi datang ke Kantor Kementerian Agama Kabupaten Lamongan.

\section{Standar Operasional Prosedur Pelayanan Kantor Kementerian} Agama Kabupaten Lamongan

Dari penelitian yang dilakukan, Kantor Kementerian Agama Kabupaten Lamongan sudah memiliki Standar Operasional Prosedur. Namun SOP tersebut belum diterapkan dalam kegiatan sehari-hari secara konsisten. Hasil observasi dan wawancara menunjukkan bahwa SOP belum disosialisasikan, dibagikan dan dimiliki masing-masing pegawai. Sebagian pegawai ada yang sudah mengaplikasikan SOP yang sudah dibuat, namun sebagian yang lain ada yang belum memahami dan mengaplikasikannya.

Mengenai kualitas dari SOP sendiri mengacu pada 7 hal pokok yang penting untuk dimiliki sebuah Standar Operasional Prosedur masih terdapat berbagai kekurangan.

Pertama, dalam hal efisiensi SOP ditemukan fakta bahwa SOP Kantor Kementerian Agama Kabupaten Lamongan kurang lengkap. Misalnya dari segi langkah-langkah kerja yang kurang rinci sehingga hal ini membuat pegawai harus bertanya satu sama lain. Hal ini membuat efisiensi dari SOP kurang maksimal.

Kedua, berbicara mengenai kelengkapan SOP, dalam SOP yang dimiliki Kantor Kementerian Agama Kabupaten Lamongan tidak tercantum proses atau alur kerja yang lengkap seperti tidak adanya flowchart pada beberapa SOP yang sudah ada. Seharusnya, untuk seluruh SOP dibuat dengan format diagram alir (Flowchart) supaya setiap pegawai dapat melihat SOP dengan mudah pada setiap tahapannya. Format ini juga dapat membantu tamu yang tidak mengerti tentang kegunaan SOP untuk mengetahui dan memahami dokumen SOP yang ada.

Pelaksanaan Standar Operasional Prosedur Pelayanan di Setiap Bidang Kantor Kementerian Agama Kabupaten Lamongan 
Dalam pelaksanaan Standar Operasional Prosedur pelayanan di setiap bidang Kantor Kementerian Agama Kabupaten Lamongan belum maksimal. Setiap bidang kantor Kementerian Agama Kabupaten Lamongan sudah memiliki SOP pelayanan sendiri. Dalam pelaksanaan pelayanannya yang dilakukan Sub Bidang kantor masih minim permberlakuan atau penerapan SOP pelayanannya. Faktanya dalam pelaksanaan pelayanan yang ada dalam setiap bidang kantor masih dilakukan secara manual, bahkan terkadang pemohon datang sendiri dalam kantor sub bidang untuk menyelesaikan urusannya.

Seperti yang dijelaskan yang diatas, dalam SOP pelayanan masih banyak yang belum memahami dalam melaksanakan pelayanan sesuai dengan standar operasional yang dibuat. Sub Bidang Kementerian Agama dalam melaksanakan pelayanan kepada pemohon atau pengguna dilakukan secara personal oleh pegawai atau petugas sub bidang kantor Kementerian Agama Kabupaten Lamongan. Terkadang dalam pelaksanaan untuk petugas pada pelayanannya masih berarakan. Maka perlu pemahaman lebih dalam pelaksanaan pelayanan melalui SOP agar tamu atau pemohon dapat menyelesaikan urusannya dengan mudah.

\section{Kesimpulan}

Manajemen pelayanan Kantor Kementerian Agama Kabupaten Lamongan di era industrialisasi 4.0 masih kurang efektif dan efisien. Pelayanan yang ada sudah baik, namun belum maksimal dan sebagian sistemnya masih bersifat manual, meskipun sudah memasuki era industrialisasi 4.0 yang semua sistemnya kebanyakan sudah menggunakan teknologi digital.

SOP di Kantor Kementerian Agama Kabupaten Lamongan kurang maksimal. Langkah-langkah kerja yang kurang rinci serta kurangnya sosialisasi dan publikasi inilah yang membuat efisiensi dari SOP kurang maksimal.

Dalam SOP yang dimiliki Kantor Kementerian Agama Kabupaten Lamongan tidak tercantum proses atau alur kerja yang lengkap, seperti tidak adanya flowchart pada beberapa SOP yang 
sudah ada. Perlu adanya pemahaman lebih dalam pelaksanaan pelayanan melalui SOP agar tamu atau pemohon dapat menyelesaikan urusannya dengan mudah.

Seharusnya untuk seluruh SOP dibuat dengan format diagram alir (Flowchart) dan dicetak supaya setiap pegawai dapat melihat SOP dengan mudah pada setiap tahapannya dan para tamu yang datang tidak kebingungan serta dapat memahami dengan mudah.

Di Era Industrialisasi 4.0 ini, segala aspek pelayanan alangkah baiknya sudah menggunakan aplikasi untuk mempermudah seluruh staff dan pegawai dalam mengerjakan tugas-tugas setiap harinya serta mempermudah layanan yang ada di kantor tersebut. Seperti aplikasi pengarsipan surat keluar-masuk agar dokumendokumen tersimpan dengan rapih dan dokumen yag dicetak kemudian disetor tidak berserakan begitu saja di kantor. Dengan demikian maka efektivitas dan efisiensi waktu bisa meningkat.

\section{References}

Purwandini, Dian Amintapratiwi dan Irwansyah. "KOMUNIKASI KORPORASI PADA ERA INDUSTRI 4.0", Jurnal Ilmu Sosial, Vol. 17 No. 1, Edisi Januari - Juni 2018

Muhammad Badri, Zulfahmi, dan Listiawati Susanti. "Efektivitas media E-Government dalam mendukung Transparansi Informasi di Kantor Kementerian Agama provinsi Riau", Jurnal Riset Mahasiswa Dakwah dan Komunikasi, Vol. 1 No. 1, Maret 2019

Siraj, Arifuddin. "Refungsionalisasi Aparat Pelayanan Keagamaan di Kantor Kementerian Agama Kota Makassar", Jurnal Ilmiah Ilmu Administrasi Publik: Jurnal Pemikiran dan Penelitian Administrasi Publik, Volume 8 Nomor 1 Januari - Juni 2018. 